\title{
"The right of the people of Ireland to the [...] unfettered control of Irish destinies": Edna O'Brien, Willful Subjects, and Counter-narratives of the Republic
}

\section{Fiona McCann}

\section{(2) OpenEdition Journals}

Electronic version

URL: http://journals.openedition.org/etudesirlandaises/4981

DOI: $10.4000 /$ etudesirlandaises.4981

ISSN: 2259-8863

\section{Publisher}

Presses universitaires de Rennes

\section{Printed version}

Date of publication: 30 November 2016

Number of pages: $69-84$

ISBN: 978-2-7535-5358-3

ISSN: 0183-973X

Electronic reference

Fiona McCann, "The right of the people of Ireland to the [...] unfettered control of Irish destinies": Edna O'Brien, Willful Subjects, and Counter-narratives of the Republic », Etudes irlandaises [Online], 41-2 | 2016, Online since 30 November 2018, connection on 01 May 2019. URL : http:// journals.openedition.org/etudesirlandaises/4981; DOI : 10.4000/etudesirlandaises.4981 


\title{
"The right of the people of Ireland to the $[. .$.$] unfettered$ control of Irish destinies": Edna O'Brien, Willful Subjects, and Counter-narratives of the Republic
}

\author{
Fiona McCANn
}

Université Lille 3 SHS/Institut universitaire de France

\section{Abstract}

This article explores Edna O'Brien's more recent fiction and demonstrates how Ireland's most prolific writer continues to systematically expose the ways in which oppression and repression operate in contemporary Ireland. Using Sara Ahmed's work on "willful subjects", I aim to show how O'Brien enshrines willfulness within the very aesthetics of her texts and, in so doing, offers a counter-narrative of the Republic.

Keywords: Edna O’Brien, Sara Ahmed, willful subjects, dissensus, counter-narrative

\section{Résumé}

Cet article aborde l'ouvre récente d'Edna O'Brien et démontre comment la plus prolixe des auteurs irlandais met en lumière les modes d'oppression et de répression dans l'Irlande contemporaine. L'article s'appuie sur les écrits de Sara Ahmed à propos des willful subjects [sujets obstinés] afin d'étudier la manière dont O'Brien intègre la notion même de willfulness dans l'esthétique de ses textes, en proposant ainsi un contre-récit de la République irlandaise.

Mots clés : Edna O'Brien, Sara Ahmed, sujets obstinés, dissensus, contre-récit de la république irlandaise

Since she published her first novel, The Country Girls, in 1960, Edna O'Brien has devoted a considerable amount of attention to exposing the failure of the contemporary Irish State to live up to the ideals expressed in the Poblacht na hÉireann proclamation of 1916. She specifically reveals the various ways in which institutions (the State, the Church) and politics (nationalist, revisionist, gender) impinge upon "the right of the people of Ireland to the [...] unfettered control of Irish destinies", one of the fundamental rights stated in the Proclamation. There is, perhaps, no Irish writer who has devoted so much of her/his work to uncovering the hypocrisy endemic to late $20^{\text {th }}$ and early $21^{\text {st }}$ century Ireland. And, as Patricia Coughlan has pointed out, the ways in which O'Brien has been "attacked, critiqued, yet simultaneously portrayed as flagrant" are indicative of her role 
as "transgressive public figure". This was perhaps nowhere more obvious than in Fintan O'Toole's scathing and completely disingenuous criticism of the content of her novel In the Forest (2002) before he had even read it. In his article, while excusing other male writers such as Eoin McNamee or John Banville for their fictionalisation of events that actually did happen, O'Toole, utterly bogged down in what Jacques Rancière would term "the ethical turn", declares, quite extraordinarily, that "[w] hat matters is not how well or badly Edna O'Brien has told the story $[\ldots]$ but whether it is right to tell it at all2". As Jacques Rancière explains, "it is because everything is representable, and that nothing separates fictional representation from the presentation of reality, that the problem $[\ldots]$ arises. This problem is not to know whether or not one can or must represent, but to know what one wants to represent and what mode of representation is appropriate to this end". Rancière also reiterates that "[c]onsensus is the reduction of the various 'peoples' into a single people identical with the count of a population and its parts, of the interests of a global community and its parts ${ }^{4 \prime}$. Edna O'Brien does not, as her fiction shows, have much truck with consensus, and positions herself rather within the realm of dissensus, bringing to the fore silenced, unheard and subversive narratives of the nation. This is evident in the censorship of her earlier work, but also, I would argue, in her later work during the 1990s and right up to the present. The aim of this article is to investigate O'Brien's most recent fiction, notably her increasing interest in political violence and war (House of Splendid Isolation [1994], her short story "Plunder" in Saints and Sinners [2011], and The Little Red Chairs [2015]), and her depiction of a politically repressive State exerting excessive control over individual bodies and behaviours (Down by the River [1996] and In the Forest [2002]). I will be suggesting that these novels and short stories by Edna O'Brien can best be read through the prism of Sara Ahmed's recent work on "willful subjects" (which also resonates with Rancière's work on dissensus), and that they constitute a powerful counter-narrative of late $20^{\text {th }}$ and early $21^{\text {st }}$ century Ireland.

\section{圈 Willful subjects and dissensus}

Sara Ahmed's Willful Subjects begins with the sinister story of "The Willful Child" by the Grimm brothers, published in 1884, and she continues to use it as

1. Patricia Coughlan, "Killing the Bats: O'Brien, Abjection, and the Question of Agency" in Kathryn Laing, Sinéad Mooney and Maureen O'Connor (eds.), Edna O'Brien: New Critical Perspectives, Dublin, Carysford Press, 2006, p. 180.

2. Fintan O'Toole, "A Fiction Too Far", The Irish Times, 2 March 2002.

3. Jacques Rancière, Aesthetics and its Discontents, [Translation Steven Corcoran], Cambridge/Malden, MA, Polity Press, 2009, p. 125.

4. Ibid., p. 115. 
a guiding line throughout her detailed and philosophically dense genealogy and phenomenology of willfulness. From the outset, Ahmed explains that "willfulness is a diagnosis of the failure to comply with those whose authority is given" and that it can also signify "compromising" as it potentially "compromises the capacity of a subject to survive". She later explains that "weakness of will is offered as an explanation of how subjects 'willingly' compromise their own welfare" and that "the diagnosis of willfulness allows the good will to appear as if it is a universal will, as a will that has eliminated signs of itself from moral agreement". As her study moves forward, she makes an interesting case for the ways in which pedagogy is harnessed from an early age to "eliminate the child's will" and explains "how to become a subordinate part of a whole can require giving up a will other than the will of the whole", particularly when the "will of the whole" is that of the nation. Edna O'Brien's fiction, I will be suggesting, is full of "willful subjects" who offer, like Ahmed does, ways of thinking about what to be willful means and what the consequences of willfulness can be. O'Brien's counter-narratives of the Republic are themselves willful and her novels peopled with "willful subjects", but, as we shall see, the degree of willfulness imputed to certain characters is

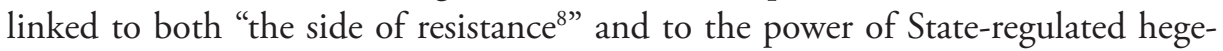
monic discourses.

Ahmed's thinking on willfulness resonates strongly, as I have noted, with Rancière's work on dissensus. One can equate Ahmed's focus on willful parts (workers, citizens, queer feminists and so on), deemed as disruptive of the common good or whole (which is universally accepted, imposed by a willful elite which is, of course, never represented as willful), with Rancière's conception of dissensus as that which pierces the status quo and renders visible and audible that which had previously been invisible and inaudible?. The focus is, admittedly, different, since while Rancière theorises the radical potential of reconfiguring the sensible as the only form of politics there is, Ahmed investigates negative perceptions of that politics and the attempts made to render it illegitimate under the pretext that it is too embedded in an individual willfulness which is fundamentally detrimental to society, the nation, and hegemonic discourses. In the fictional worlds she creates, Edna O’Brien does something similar, and this may account

5. Sara Ahmed, Willful Subjects, Durham/London, Duke University Press, 2014, p. 1. In the Grimm story, the child is killed because of her willfulness.

6. Ibid., p. 81.

7. Ibid., p. 95 .

8. Ibid., p. 177.

9. Rancière has written extensively about dissensus and how he understands, but see for instance: Jacques Rancière, Dissensus: On Politics and Aesthetics [Translation and Introduction Stephen Corcoran], London, Bloomsbury, pp. 37-9. See also Rancière's writing on "politics" (which, for Rancière is another way of expressing dissensus): Jacques Rancière, Disagreement: Politics and Philosophy [Translation Julie Rose], Minneapolis, University of Minnesota Press, 1999, p. 21-42. 
for the portrayal of the author herself as a "willful subject", a maverick "part" who works against the national "whole" and who is often dismissed, in the manner of O’Toole, as illegitimately (willfully) taking contemporary Ireland as her subject matter.

\section{圈 Willful bodies}

In many ways, Mary McNamara, the teenage protagonist of O'Brien's fictionalisation of the infamous "X Case", Down by the River, is presented as a "willful child", and the author clearly plays with perceptions of willfulness throughout the novel, not least in the choice of onomastics. Mary is the biblical name of both the Virgin and the prostitute and as the legal wrangling goes on, her name changes from Mary (in the domestic sphere) to Magdalene (in the public, media sphere), ostensibly to protect her identity. In a grotesque parody of the Bible, Mary embodies the Virgin, keeping silent about the male progenitor, although here the Immaculate Conception is utterly subverted, the father replacing (God) the Father, brutally raping his daughter several times. The shift to Magdalene in the media allows O'Brien to expose a general sense of Mary's underlying guilt and resonates with the notorious Magdalen laundries, which housed thousands of women with the full complicity of local communities. O'Brien is therefore gesturing towards a history of Irish women's "willful bodies" which must be controlled, policed, repressed, and judged by the State, yet which refuse to allow this, pushing towards dissensus and the exposure of patriarchal attitudes. Other names carry some significance in the novel: Mary's friend Tara is linked through her name with ancient Ireland, although she ironically breaks free of all associations of land/Ireland as woman, fully embracing her burgeoning sexuality and refusing to be bridled by her conservative mother ${ }^{10}$; the teenage girl Mary meets at the abortion clinic in London, and who goes through with her abortion, is named Mona, which originally means "noble one", deriving from the Irish Muadhnat, a name which gestures towards her brave decision and her compassionate behaviour towards Mary; the lawyer who presents a convincing case for Mary's right to travel to the Supreme Court, and wins, is significantly called L'Estrange, a name which draws attention to his otherness or foreignness within the closed-circuit snobbery of the legal profession ("he despises them all, is above them all") and to his related

10. It is worth pointing out that O'Brien also acerbically evokes how, because sexuality is so repressed, Tara's only source of knowledge about sex is from teenage magazines which, although they may encourage sexual activity, also couch it in terms which privilege male sexual climax and put pressure on teenage girls to conform to a certain norm: "Turn him on with a sassy walk or your fave raunchy film"; "Slather him in ice cream and lick it off”; "Get him to pull out in time. Keep asking yourself am I climaxing”. Edna O’Brien, Down by the River, [1996] London, Phoenix, 1997, p. 30. 
willingness to take on cases no one else will ("He's taken cases no one else would touch") ${ }^{11}$. Only the stranger, it would seem, he who is not willing to fit in, can make, and win, this case.

Mary's body comes under intense scrutiny in the novel as a space of transgression. The first violation by her father shifts the emphasis from a rape which she cannot prevent and an intrusion into her body ("a feeling as of having half-died") to a sexual encounter she has elicited when he says "What would your mother say... Dirty little thing ${ }^{12 "}$, thus imputing to her an agency he has specifically denied her. In the later encounter which results in the pregnancy, O’Brien carefully emphasises the detrimental effect for Mary of expressing her will to extricate herself from the situation: "if she shouted now it would only worsen things ${ }^{13}$ ". This is a case of what Ahmed explains as "[b]ecoming willing to bear" so as "to avoid the costs of not being willing to bear" since "[s]ubjects might become willing if not being willing is made unbearable ${ }^{14}$. In the context of Down by the River, the idea of "bearing" is particularly relevant subsequently, since the rest of the novel deals with Mary's lack of agency in the decision to "bear" or not the foetus to term. She literally becomes willing because she is faced with the full weight of the nation's disapproval, despite the fact that she has tried to kill herself. From the rape to the pregnancy, Mary is unable to express any willfulness which would go against the dominant discourse, yet as O'Brien shows, this does not prevent her from being perceived as willful for all that.

As Ahmed painstakingly explains, "[w] hen willing 'agrees' with what is generally willed, a part becomes part of a background. When willing does not agree, the will of the part is too full: willful 15". She goes on to develop this idea of how "the general will" can have a negative impact on individual wills, stating that "[ $t]$ he figure of the willful child becomes crucial to the national project, allowing that project to be framed as a matter of life and death: the project of straightening the children becomes about saving the nation ${ }^{16 "}$. In this novel, O'Brien reveals how Mary (and her real life counterpart) becomes "crucial to the national project" of Ireland as an abortion-free country. This national ideal is also once again expressed in onomastics, since the self-styled leader of the pro-life movement is named Roisin, which means little rose, and as such evokes one of the many symbols of Ireland reinvigorated during the Celtic revival ${ }^{17}$. Perhaps the most

11. Ibid., p. 187.

12. Ibid., p. 5, ellipsis in original.

13. Ibid., p. 97.

14. S. Ahmed, Willful Subjects, op. cit., p. 139.

15. Ibid., p. 121, italics in original.

16. Ibid., p. 130.

17. For a discussion of the overlap between the rose and Ireland in Yeats's poetry and in contemporary poetry, see Vicki Mahafey, States of Desire: Wilde, Yeats, Joyce and the Irish Experiment, Oxford \& New York, OUP, 1998, p. 106-123. 
willful character of the novel, Roisin is not perceived as such by the characters in the novel because her will corresponds to that of the hegemonic discourse, that of "straightening the children" and "straightening the nation". The violence with which she presents abortion to a group of rural parishioners is nevertheless suggested by the narrative voice which stipulates that " $\mathrm{r}] \mathrm{ammed}$ down their throats are the details" of abortion, and by the inclusion of a detailed description of the poster she shows them: "a torn baby, its body mangled, pools of black blood in the crevices and in the empty crater of its head ${ }^{18}$ ". However, Mary's will "not to bear" either the situation or the baby is clearly presented in a note she writes to herself and the "child": "it is just that I cannot bear you ${ }^{19}$ " and O’Brien suggests, in an ironic twist (although it is based on fact) that Mary's will dovetails with "God's will20" when she miscarries just as the Supreme Court decision reaches the group of women who are minding her. Roisin promptly accuses her of having "willed $\mathrm{it}^{21}$ ", which is more or less true, and O'Brien clearly emphasises (and rewards) Mary's strength of will, even in the midst of physical, sexual and psychological abuse. The self-importance of "the corporeal figures of knowledge and

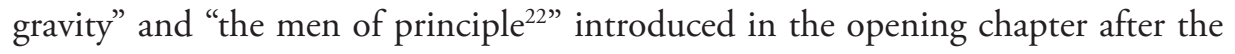
first rape is ultimately subordinated to Mary's own will at the end of the novel, a will which O'Brien celebrates in the final paragraph in a poignant description of Mary's voice singing a solo at a cabaret, a voice which is "in answer to [the public's] own souls' innermost cries $^{23}$ ".

The more negative consequences of attempting to "straighten the children" are evoked in In the Forest through two willful figures, Michen O'Kane and Eily Ryan, attacker and victim. Both characters are perceived as too willful for their own good (it is no coincidence that they both end up dead) and I have investigated elsewhere the ways in which O'Brien draws attention to Eily's otherness within the community because of her alternative lifestyle and free sexuality ${ }^{24}$. What I would like to develop here is how O'Brien indicts that community and, by extension, the nation, by revealing the failure of the "poisonous pedagogy $y^{25}$ " deployed and by expressing an alternative possibility for rehabilitating willfulness in the final chapter of the novel.

18. E. O'Brien, Down by the River, op. cit., p. 17.

19. Ibid., p. 267.

20. Ibid., p. 291.

21. Ibid.

22. Ibid., p. 6.

23. Ibid., p. 298.

24. See Fiona McCann, “Towards an Aesthetics of Violence: Edna O’Brien's In the Forest and Anna Burns' Little Constructions", Bertrand Cardin \& Sylvie Mikowski (eds.), Écrivaines irlandaises, Caen, Presses universitaires de Caen, 2014, p. 117-131.

25. This is the term used by Sara Ahmed to describe the process by which education is a tool used by society for "breaking the child's will", often as part of a national project. S. Ahmed, Willful Subjects, op. cit., p. 62. 
O'Kane's early assertion of his own will is related to a situation of domestic abuse and is in opposition to an abusive father. As Ahmed shows, "the rod" is widely perceived as "the proper instrument for moral correction" and as one of the "techniques of parental will26". With this in mind, one is tempted to read the act of transgression for which the ten-year old O'Kane is eventually sent to a detention centre (stealing a gun) as a willful attack on patriarchal authority, since he cuddles it and significantly "call[s] it $\operatorname{Rod}^{27}$ ". His intention is not to hurt anyone with it, but the very possession of it is, for the patriarchal trilogy of the father, the sergeant and the judge, evidence of "the moral danger of willfulness ${ }^{28}$ " which must be eliminated. It also evokes, from the outset of the novel, the dangers inherent to this type of "poisonous pedagogy" and functions as an early sign of the way "those beaten by the rod become the rod that beats ${ }^{29}$ " since O'Kane will subsequently become a murderous figure to the physical, sexual and psychological abuse he suffers in the detention centre. This failure to contain is clearly expressed at the moment of O'Kane's capture, after he has killed Eily, her son, and a local priest, when the villagers "are afraid of him now, the Kinderschrek, one of their own sons, come out of their own soil, their own flesh and blood, gone $a^{3}{ }^{30}$ ". The triple acknowledgement here of O'Kane's belonging to this community (geographically and genetically), offset by the use of the derogatory nickname which functions as a distancing mechanism, is the moment of recognition of a willfulness which has been exacerbated by "poisonous pedagogy", with disastrous consequences.

The final chapter of the novel, entitled "Scallywag", appears as something of a postscript, disconnected as it is from the diegesis of the novel. Less than two pages long, it is a short story about a little boy who wanders into a wood, loses track of time, and is feared missing by his worried family. The characters in this chapter all remain nameless, so as to reinforce the moral, which is clearly a plea for perceiving willfulness as a gift rather than a threat ${ }^{31}$. Framing the novel with, on the one hand, O'Kane's escape into the wood which goes unnoticed because of an abusive father, and, on the other, this chapter which celebrates the young boy's creative imagination, O'Brien draws attention to the potential for a reconfiguration of willfulness which resonates with Ahmed's final thoughts on the matter. The wood

26. Ibid., p. 65.

27. Edda O’Brien, In the Forest [2002], London, Phoenix, 2003, p. 3.

28. S. Ahmed, Willful Subjects, op. cit., p. 68.

29. Ibid., p. 67.

30. E. O'Brien, In the Forest, op. cit., p. 232.

31. Sara Ahmed makes this very plea in the final pages of her work. In a turn of phrase reminiscent of Rancière's thoughts on dissensus (or politics) as a disruption of the sensible order, she makes a case for embracing willfulness as a means of "relat[ing] differently to the capacity of all things to deviate from the places given as assignments", and stresses that "disturbance can be creative". S. Ahmed, Willful Subjects, op. cit., p. 191, p. 204. 
which was frightening for O'Kane is idyllic for this young boy and while no one notices O'Kane's disappearance, the idiomatic expression "the whole country was out looking for [the scallywag] ${ }^{32}$ " symbolically suggests that not only are people literally looking for the boy, but also that attitudes have shifted and that "the whole country" is looking out (in the sense of caring) for him. The farmer who finds him calls him a "scallywag". This is a term of endearment and a recognition of willfulness, in marked contrast with O'Kane's nickname, "Kinderschrek". The boy's willfulness is enshrined in the final sentences of the novel, "They'd never know, they'd never get to the bottom of it and they shouldn't. Magic follows only the few ${ }^{33}$ ". A call for creativity and adventure, O'Brien ends an otherwise disturbing and somewhat depressing novel on this more positive note.

\section{圈 Willfulness as "political craft"}

The final chapter of Ahmed's work focuses on willfulness as a potential form of political action and offers a "way of thinking of sovereign will" as "the right to determine whose wills are the willful wills5". House of Splendid Isolation and The Little Red Chairs are the two novels in which O'Brien tackles political violence most overtly. The former marked an interesting new departure in the author's work and in her memoir she evokes the conviction that she needed to find a story to write about the Troubles and the "sneering insinuation that [she] was 'sleeping with the Provos'36" once she did. Her sympathetic portrayal of McGreevy in House of Splendid Isolation is part of O'Brien's project of dissensus, since in the literary landscape of the 1990s (and still today) the dominant aesthetics of the Troubles and, in particular, the IRA, was the representation of bloodthirsty, atavistic criminals. As Judith Butler has argued in Precarious Life, the way in which the word "terrorist" is used excludes from sight State-endorsed forms of violence, and how some lives become more grievable than others as a result ${ }^{37}$. This is what O'Brien is eager to expose in this novel in her portrayal of the tense relationship between Josie, the elderly owner of the Big House, and McGreevy, an IRA volunteer on the run after a botched military operation.

The opening chapter of the novel, which is subsequently attributed to an unknown narrator who turns out to be the disembodied child that Josie aborted, emphasises the importance of point of view in any (hi)story: "History is everywhere.

32. E. O'Brien, In the Forest, op. cit., p. 273.

33. Ibid.

34. S. Ahmed, Willful Subjects, op. cit., p. 133.

35. Ibid., p. 136, italics in original.

36. Edna O’Brien, Country Girl, A Memoir, London, Faber \& Faber, 2012, p. 236.

37. Judith Butler, Precarious Life: The Powers of Mourning, London, Verso, 2004. 
[...] The tale differs with the teller ${ }^{38}$ ". This functions as a metafictional warning of sorts in which O'Brien obliquely stakes her claim to an alternative perspective on the contemporary Troubles, and rather than being a novel whose "lesson" is "that history should be laid to rest" ${ }^{39}$, House is more about accepting multiple versions of the past and accepting that perceptions can be erroneous. This is particularly obvious at the end when one of the Guards mistakes the attempts by Josie and McGreevy to chase wasps out of the room as a "lewd, disgusting ${ }^{40}$ " sexual encounter. It is also evident in the shifting points of view which pit the authorities' view of McGreevy as "terrorist" and "animal ${ }^{41}$ " (amongst other slurs) against the sensitivity and pragmatism of the McGreevy who Josie gets to know ${ }^{42}$. Finally, when a local man, Martin, comes snooping round Josie's house, his smutty and violent thoughts are in complete opposition with the reserve and respect shown by McGreevy: "he would snuff her, there and then, take her by the neck and hold her till there was not a drop of breath left. [...] $[\mathrm{H}]$ unt her orchid and a man would find what - Sheela-na-gig' ${ }^{243}$ ". The excess of violence, coupled with the allusion to the architectural grotesques featuring an exaggerated vulva, expose the hypocrisy at work: while McGreevy is considered as so willful that he is a danger to society, men like Martin, who uphold the status quo, are able to give free rein to their sexist and murderous urges.

The Big House, as the title suggests, is central to the novel and to O'Brien's project of providing a counter-narrative of the nation. Josie, as she reminisces on

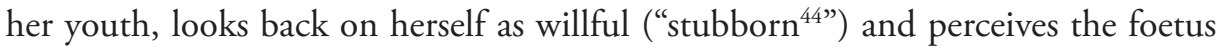
she did not carry to term as "more like a banshee than a child 45 ". She also reflects, twice, on "the house she had married into" 46 " rather than on the husband she married. The house becomes a metonymy not just for wealth and power, but also for her violent husband who rapes her as a means of countering the willfulness he perceives in her. Other critics have noted the significance of the Big House in the novel as a space in which History is reconfigured, where the representative of the Ascendancy shares a meeting of minds with that of contemporary republicanism ${ }^{47}$. It is significant that the house should be burnt down at the end of

38. Edna O'Brien, House of Splendid Isolation [1994], London, Phoenix, 1995, p. 3.

39. Heather Ingman, "Edna O’Brien: Stretching the Nation's Boundaries", Irish Studies Review, 10, 3 (2002), p. 261.

40. E. O’Brien, House of Splendid Isolation, op. cit., p. 208.

41. Ibid., p. 11, 70 .

42. For a discussion of this aspect of the novel and the postmodern narrative techniques deployed by E. O'Brien, see Michael Harris, "Outside History: Edna O’Brien's House of Splendid Isolation", New Hibernia Review, Vol. 10, n ${ }^{\circ}$ 1, Earrach/Spring 2006, p. 111-122.

43. E. O'Brien, House of Splendid Isolation, op. cit., p. 109, italics in original.

44. Ibid., p. 48.

45. Ibid., p. 46.

46. Ibid., p. 38, 39 .

47. See Ingman, Harris, op. cit., as well as the following articles: Iris Lindhal-Raittila, "Negoiating Irishness: Edna O’Brien's 1990s Trilogy", Nordic Irish Studies, Vol 5, 2006, p. 73-86; Sophia Hillen-King, "On the Side of 
novel, but the decline of the house and what is represents has already begun long before this, notably in the local folklore which points out that no children have ever been raised in this home, underlining the end of the lineage. The house is in fact ultimately reduced to another kind of architectural grotesque: "The stairs askew with a hat stand wrapped around it, and an old fur coat hanging jauntily off. Inside is worse. In the back where the explosive went off, wood, metal and glass are in weird configurations, remainders of wall wobbling like loose teeth in a gum and a fierce and innocent mass of paint, where a picture of Christ and the virgins has been splashed and muralled onto a wall ${ }^{48}$." Bearing all the hallmarks of a grotesque body, the house, reduced to the signifiers of wealth (the hat stand and fur coat), is dead, just as Josie is tragically shot in a case of mistaken identity. O'Brien appears to be suggesting that the Big House and what it represents is now obsolete and grotesque, replaced by an ambivalence among the Guards about the right attitude to adopt: "Half of you hopes you got him and the other half hopes you didn't"; "We're all Irish under the skin ${ }^{49}$." What this underlines is the way in which IRA activity, and ambivalent attitudes towards it, are evocative of the failure of the collective will, since the parts no longer fully agree on what "the national will ${ }^{50}$ " constitutes. This is partly because McGreevy is perceived as a foreigner, as not belonging to the land, a point which is reinforced in Josie's diary: "'The South forgot us', he said. Aggrieved. A likeness to those children in fable banished, exiled in lakes for hundreds of years, cut off from the homeland ${ }^{51}$ ". McGreevy is clearly associated here with the "willful child" figure of the fairy tale, disbarred from "becom[ing] a member of the national body ${ }^{52}$ " yet the young Guard's remark, quoted above, about them all being Irish "under the skin" disturbs the national narrative, complicating it, and is indicative of O'Brien's attempts through this novel to present a more complex view of the political situation in Ireland.

Her much more recent short story "Plunder", published in the award-winning collection Saints and Sinners in 2011, although fable-like in its aesthetics, appears to develop her interest in political violence. Although not ostensibly set in Ireland, one reference to a character playing "Boulevouge ${ }^{53}$ " anchors it firmly in Ireland and within a tradition of resistance, since "Boulevouge" is an Irish ballad about a priest, Father John Murphy, who actively participated in the 1798 rebellion, and

Life: Edna O’Brien's Trilogy of Contemporary Ireland”, New Hibernia Review/Iris Eireannach Nua, Vol. 4, $\mathrm{n}^{\circ} 2$, Summer 2000, p. 49-66.

48. E. O’Brien, House of Splendid Isolation, p. 210.

49. Ibid., p. 177.

50. S. Ahmed, Willful Subjects, op. cit., p. 127.

51. E. O'Brien, House of Splendid Isolation, op. cit., p. 99.

52. S. Ahmed, Willful Subjects, op. cit., p. 126.

53. Edna O'Brien, "Plunder", Saints and Sinners, London, Faber \& Faber, 2011, p. 80. 
was composed for the centenary in 1898. As such, it is one of many rebel songs which are part of republican repertoire. The story itself is the account by a young, first person female narrator of a military invasion of the territory in which she lives, the brutal behaviour of the foreign soldiers towards the locals (particularly the women), the gradual erosion of the indigenous language, her eventual capture and gang rape, and her strong survival instinct which is asserted in the final lines of the story.

The language of the story is sparse and minimalist, thus giving the impression that the narrator is young, an impression which is subsequently reinforced by her reference to her mother and siblings. In some ways evocative of JM Coetzee's Waiting for the Barbarians (1980) ${ }^{54}$, O'Brien's tale of military hypermasculinity and its impact upon women in particular is atemporal, although the initial impression that it is set in pre-modern times is undermined by references to rudimentary technology for searching for car bombs, thus blurring the temporal frame of the story. Spatially, as in Coetzee's novel, there is nothing to indicate where the story takes place, even though the opening sentence clearly posits territorial transgression as the main issue: "One morning we wakened to find that there was no border - we had been annexed to the fatherland ${ }^{55}$." The use of the passive voice here immediately draws attention to the absence of agency of the narrator and her fellow citizens, while the reference to the "the fatherland" suggests a colonial and patriarchal relationship between this unnamed territory and that of the intruders. This patriarchal and neighbouring land also functions as a violent, surrogate father since the narrator reveals that "our father had disappeared long ago $^{56 "}$, without offering any explanation why. Gradually, the mother is taken by the foreign soldiers, sexually assaulted, never to return, and the land is, as the title suggests, gradually plundered. The narrator also indicates that there are more than one set of soldiers who "swapped sides the way they swapped uniforms ${ }^{57}$ ", suggesting a fratricidal conflict reminiscent of the Irish Civil War.

The story is broken down into two parts, separated by a space in the text, and the main difference between the two parts is the move from the first person plural pronoun, "we", to the first person singular "I". This shift is not only representative of the gradual murder of every member of her family, but also of the emergence of the voice of individual testimony. The extreme brutality of the description of the gang rape anticipates the almost unbearably violent scenes in The Little Red Chairs, O’Brien's most recent novel, to which I will return shortly. The nar-

54. This is not just stylistic, or thematic. There is an obvious nod to Coetzee's novel when the narrator explicitly evokes a time "before the barbarians came". O’Brien, "Plunder", op. cit., p. 81.

55. Ibid., p. 77.

56. Ibid. p. 78.

57. Ibid., p. 81. 
rator in "Plunder" is reduced to an object, as the numerous passive constructions reflect: "[He] tossed me", "He sat me on his lap, wedged my mouth open", "he splayed me apart", "I was turned over", "they bore through me $\mathrm{e}^{58}$.

Her body is literally plundered, in the same manner that the land and livestock have been plundered, by the soldiers. However, for all that, the spunky narrator, who has tried to resist the new "sovereign will" by not forgetting the time before (hence the numerous comparisons with a past which, though not idyllic, is certainly presented as much more enviable than the present) and by ultimately discovering "a will that has not been fully eliminated 59 ". This is expressed firstly in her assertion that although the soldier-rapists "want[ed] to get up into my head", they "couldn't get to it", and secondly, in her focusing not on what is being done to her body, but on a pair of buzzards gliding in the blue sky ${ }^{60}$. For Ahmed, "reaching for will" can be "an opening up of the body to what came before, reaching as going back in time", in other words, "a recovery of the collective", notably through the way in which "bodies can remember what has not been fully erased from themselves ${ }^{61}$ ". Edna O'Brien ends her story with the unnamed narrator evoking, in the wake of the gang rape which has almost left her dead, her past simple yet satisfying life with her mother. She thinks in particular of an alarm clock for which they could not afford batteries and the way in which they told the time by being attentive to light and the rhythms of nature. We are invited to see this not just as "a recovery of the collective", but also as a metaphor for alternative modes of existence and a temporality based on the natural, as opposed to man-made world. This is all the more significant as an act of will as the leader of the soldiers who rape her is named "Head Man". "Head" might be understood here as leader, the one in charge, or the brain, as in the man who thinks (or wills). The fact that the soldiers cannot "get up into [her] head" is therefore all the more significant, since it signifies both her will to resist psychological intrusion and her rejection of what the "Head Man" represents"

The story ends with the narrator's resolve to get up and go in search of other survivors and although the final sentence gestures towards a grim future ("Many and terrible are the roads to home ${ }^{63 "}$ ), the emphasis of the penultimate paragraph which precedes the final sentence is on the "recovery of a collective" and "a shared

58. Ibid., p. 82.

59. S. Ahmed, Willful Subjects, op. cit., p. 140.

60. E. O'Brien, "Plunder", op. cit., p. 82-3.

61. S. Ahmed, Willful Subjects, op. cit., p. 140.

62. One might also be tempted to see this as a little essentialist in its presentation of the foreign occupier as "Head Man" and the local indigenous as associated with nature, as it vaguely reproduces familiar colonial stereotypes. I would suggest, however, that by naming the brutal soldier "Head Man", O'Brien is mocking him, since it is the "Head Man" here who is governed by his baser drives.

63. E. O’Brien, "Plunder", op. cit., p. 84. 
inheritance ${ }^{64}$. But this fable-like story begs the question of the agendas at stake. In a collection the title of which nods ironically and critically to the self-aggrandising idea of Ireland as a nation of saints and scholars, and in which most of the stories deal with contemporary Ireland $\mathrm{d}^{65}$, it is tempting to read this story as an allegory of the violence of neo-liberalism in contemporary Ireland. Borders are nebulous in this story, disappearing and appearing, and the question of annexation to a fatherland quite possibly evokes Ireland's handcuffing to Troika imperatives, especially given the historical associations of Germany (perceived in Ireland as the main instigators of Irish economic subservience post-2008) and the notion of "fatherland". If this is the case, then O'Brien is emphasising with uncharacteristic violence the economic plunder of Ireland, the price to pay for Irish people of the bailout ("plunder"), the absence of resistance ("Boulevouge" is now just a form of brief entertainment and holds no revolutionary possibility), and the uncertainty of any "safe haven ${ }^{66 "}$ ".

This idea of a "safe haven" is also rendered highly problematic in O'Brien's most recent novel, The Little Red Chairs. Set mostly in Ireland, but also partially in London, it is the story of the arrival in a rural community of an enigmatic and charming Serb, Dr Vladimir Dragan, who sets up shop as a healer of sorts, has a brief liaison with a local women who becomes pregnant, and is then spectacularly arrested and brought to the Hague, charged with crimes against humanity during the Balkans war. Fidelma, pregnant by him, is then kidnapped by three Serbian men who are intent on getting revenge on the doctor and who savagely provoke an abortion, leaving her for dead. The second part of the novel deals with Fidelma's reconstruction. The plot obviously gestures in ways to Synge's Playboy of the Western World, with the arrival of this seductive stranger who is welcomed by the gullible locals who defer to his wisdom and who allows them to express their otherwise repressed interest in esoteric practices and latent sexual drives (as opposed to the repressed violent drives in Synge's play). Yet it is just a gesture, as O'Brien's protagonist is no Christy Mahon, unsure of himself and given substance by the narrative the locals create for him. Dr Vlad, as he is nicknamed, is unapologetically guilty of ethnic cleansing and the mass murder of hundreds of Bosnian Muslims, including children, and feels himself utterly superior to the villagers, as several passages narrated from his point of view demonstrate ${ }^{67}$.

64. S. Ahmed, Willful Subjects, op. cit., p. 140.

65. Indeed, political violence is also broached in a less oblique or symbolic fashion in the story "Black Flower" which immediately precedes this one in the collection. For a discussion of the story, see Fiona McCann, $A$ Poetics of Dissensus: Confronting Violence in Contemporary Prose Writing from the North of Ireland, Bern, Peter Lang, 2014, p. 155-159.

66. E. O’Brien, "Plunder", op. cit., p. 84.

67. The character is based on the real-life character of Radovan Karadžić, known as the "Butcher of Bosnia", who hid in plain sight as a healer/sex therapist in Austria before being captured and brought to The Hague where 
A full discussion of this novel would require more space than I have left, but I would like to dwell briefly here on O'Brien's focus on the migrant figure and link it to Ahmed's study of willfulness. Migrant figures abound in The Little Red Chairs, from the figure of Dr Vlad to the migrant workers at a local hotel, to Fidelma herself as she is ostracised from her husband and her community for her adultery and migrates to London where she comes in contact with yet more migrants from various war-torn parts of the world. Several chapters in which dialogue (as opposed to description) is dominant give voice to the migrant experience: in "On the Veranda", each foreign character working in the Castle near the Irish village tells his or her story to the others and later, in "The Centre", a group of migrant "survivors" in London tell their stories of war, precarious existence, and resilience. These stories of homelessness, love, jealousy, mutilation, tradition, sexual assault, and war mix the banality of human life with the exceptional and give the lie to xenophobic discourses which present "the unwilling migrant" as "unwilling to integrate ${ }^{68 "}$. All the migrants, including Fidelma, are expected to "counter the willfulness charge" lest they should be perceived as "dislocat[ing] the national body, causing discomfort ${ }^{69}$ ". They do so by fitting in, taking on menial jobs, keeping their heads down, and by subordinating their will to that of the nation-state in which they find themselves. Yet the sharing of stories in these two key chapters functions as a means of exposing the "diversity of individual parts", without for all that showing "an attachment to an unassimilable difference ${ }^{70 "}$. The only migrant character who appears as willful is Mujo, who takes refuge in silence, refusing to share his story, and thus refusing to be subsumed into a homogenous migrant narrative. Mujo's later refusal to serve Dr Vlad, whom he recognises for the war criminal he is, is perceived as outrageous by the hotel management, and through this episode O'Brien exposes their obsequiousness towards the revered stranger and draws attention to a very Irish deference to external authority.

Fidelma is sorely punished for her willful adultery and her flouting of convention. She is judged after her attack by her husband, local police and the medical staff for her transgression ("The others stood around the bed in judgement ${ }^{71}$ "), and there is no sympathy forthcoming for the ordeal she has experienced. Both her attackers and the only local woman who has guessed Fidelma is pregnant agree that she should not have this child, Mona because of her discovery that Dr Vlad is guilty of the most heinous war crimes and because she clearly fears that

he was charged with war crimes. O’Brien even includes some of Karadžić's poetry in the novel. Edna O'Brien, The Little Red Chairs, London, Faber \& Faber, 2015, p. 129.

68. S. Ahmed, Willful Subjects, op. cit., p. 128.

69. Ibid., p. 129.

70. Ibid., p. 128.

71. E. O’Brien, The Little Red Chairs, op. cit., p. 151. 
this child could become "the wayward branch of a family tree that threatens the legitimacy of the national trunk ${ }^{72}$ ", and her attackers because they want to get revenge on their old comrade. While Mona plans to convince Fidelma to have an abortion, her attackers literally subject her to the rod, violently provoking an abortion. In a grotesque variation of the rod as a tool for chastisement, the attackers discipline Fidelma and physically eradicate the existence of the potential willful child she is carrying.

For all that, the will to survive is presented as strong in this novel. The final chapter is entitled "Home" and is narrated by Fidelma who has since been forgiven by her husband who is now dead. "Home" is now the centre in London where "the world comes in [...] every day" and Fidelma's new moniker is "Delphi", suggesting through the etymology that from her womb (and her experiences) something fruitful has issued in the form of this drop-in centre for migrants in difficulty. The final passage describes "a very free interpretation of A Midsummer Night's Dream ${ }^{74 "}$ put on in the centre by the migrants. This bastardised version of the Shakespearian comedy mixes classic lines from the play with contemporary life expressed in the vernacular (pizza delivery, children's buckets and spades, among other incongruous elements), and ends with the word "Home" being "sung and chanted in the thirty-five different languages of the performers ${ }^{75}$ ". The discordant choir of voices lack harmony and sing "awry", but the point O'Brien is trying to make is precisely that it is this very discordance which should be celebrated. The power of these migrants' voices to transcend borders and spaces is emphasised in the imagined shift from the centre to "the lit street, to countryside with its marsh and meadow, by graveyard and sheep fold, through dumbstruck forests, to the lonely savannahs and reeking slums, over seas and beyond, to endless, longed-for destinations". These willful voices, resistant to an overarching harmony, ultimately make "savage music ${ }^{76 "}$ and enshrine willfulness as a positive dynamic, resonating with Ahmed's idea that "willful subjects can recognise each other, can find each other, and create spaces of relief, spaces that might be breathing spaces, spaces in which we can be inventive ${ }^{77 "}$. O'Brien clearly suggests the positive potential of creation and of willful deviance from canonical forms of expression.

This brief panorama of Edna O'Brien's more recent fiction has, I hope, shown to what extent this important and prolific Irish author has developed a poetics

72. S. Ahmed, Willful Subjects, op. cit., p. 130.

73. E. O'Brien, The Little Red Chairs, op. cit., p. 293.

74. Ibid., p. 295.

75. Ibid., p. 297.

76. Ibid.

77. S. Ahmed, Willful Subjects, op. cit., p. 169. 
of willfulness aimed at uncovering a sometimes sinister picture of contemporary Ireland and the repression of individual wills which threaten the integrity of the national will. Her fiction does not directly respond to the Proclamation of 1916, but it certainly exposes the limits imposed on the citizens of Ireland, the repressive policing of behaviour, and the failure of the State to enable its inhabitants to have "unfettered control over [their] destinies". Her most recent novel is testimony to the ways in which O'Brien has incorporated changes in Ireland into her fiction and recognised global influences, good and bad. After nearly sixty years writing about willfulness, Edna O'Brien shows no sign of ceasing to play her own role as "willful subject". 